\title{
HISTORICAL LINGUISTICS, LINGUISTICS, AND APPLIED LINGUISTICS: A STUDY INSPIRED BY TREES ${ }^{1}$
}

\author{
María del Carmen Arau Ribeiro, Instituto Politécnico da Guarda, Portugal \\ Email:mdc1792@gmail.com
}

\begin{abstract}
This innovative perspective on historical linguistics, linguistics, and applied linguistics examines these areas of study with the role of trees in mind. It covers the quest for the founding father of historical linguistics - from the German Schleicher through the Scots, Stewart and Hutton, to the Americans, Whitney and Peirce, and the Swiss, Saussure. A brief but sweeping review of early linguistics and language study before the advent of cognitivism reveals American structuralism and immediate constituent analysis in descriptive linguistics relying on the tree structure even prior to the time transformative generative grammar was institutionalized.

Keywords: Historical Linguistics, Linguistics, Language Teaching, Trees.

Título en español: La lingüística histórica, la lingüística, y la lingüística aplicada: Un estudio motivado por los árboles.

Resumen: Esta perspectiva original sobre la linguística histórica, la linguística, y la linguística aplicada examina estas áreas de estudio desde un punto de vista arbóreo. Cubre la búsqueda de un padre fundador de la lingüística histórica - desde el alemán, Schleicher, y los escoceses, Stewart y Hutton, a los norte-americanos, Whitney y Pierce y el suizo, Saussure. Una breve pero vasta revista de la primitiva lingüística y el estudio de lenguas antes de la aparición del cognitivismo revela que el estructuralismo americano y el análisis de los constituyentes inmediatos en la lingüística descriptiva dependen de la estructura arbórea incluso antes que la gramática generativa transformativa fue institucionalizada.

Palabras Claves: Lingüística Histórico, Lingüística, Enseñanza de Lenguas, Árboles
\end{abstract}

In his plenary speech at the Oxford University Press-The New School ELT Professional Development Series talks in New York City, and as one of the founding faculty members of the M.A. in TESOL program at The New School for General Studies, Thornbury (2009) commented that a major difference between studying linguistics and language teacher training on either side of the Atlantic Ocean was the omnipresence of tree diagrams in the United States. His note prompted this broad examination of language from historical linguistics to language teaching, tracing along the way the historic role of trees in these areas in an attempt to contribute to this scholarly discussion.

Date of reception: 15 June 2011

Date of acceptance: 12 July 2011

Odisea, nº 12, ISSN 1578-3820, 2011, 39-52 


\section{HISTORICAL LINGUISTICS}

Language teaching begins in the research dedicated to understanding language although academics have yet to unravel the complexity of the communication tool that is language. Just as Aitchison (2008) referred to the articulate mammal in her original 1976 book with the homonymous title; it is specifically this articulation that is the study of early philologists ${ }^{2}$ who focused especially on historical and comparative linguistics; as such, the title of founding father of historical linguistics would be so prestigious that it is widely claimed from a wide array of research areas, from paleontology to theology.

At the Missing Links Conference held in Denmark in 2006, Niels Bonde, senior lecturer emeritus at the Geological Institute of Copenhagen University, Denmark, noted that August Schleicher (1821-1868) had earned the right to be called the father of historical linguistics, attributable to the influence of Charles Darwin's (1859) use of a tree-like diagram; Schleicher's 1853 publication $^{3}$ of a stammbaum $^{4}$, however, precedes Darwin's 1859 influential drawings of evolutionary trees. Schleicher is instead credited with having convinced Darwin of four areas in which the historical linguistic model could influence his developing theory of evolution (Richards 2001). The pattern of language descent, therefore, mirrored the pattern of human descent as follows: (1) that based on the developmental history of languages, a natural history of the genus homo could be displayed; (2) since he had shown that languages are natural organisms ${ }^{5}$, whose advantage over other natural organisms is based on linguistic evidence, likened to fossils, of earlier and even primitive forms of language; (3) that the processes he had identified for competition among languages/simple roots and their resulting extinction and/or developing complexity seemed to parallel the processes ruling the evolution of species; and (4) that the theory that the advanced species descend from simpler forms finds its correspondent in the historical cellular language ${ }^{6}$ that resulted in various language groups.

Schleicher's (1874) great linguistic achievement was also the work translated into English as A Compendium of the Comparative Grammar of the Indo-European, Sanskrit, Greek, and Latin Languages ${ }^{7}$, in which he perfected his notation of the development of languages. Forming a duo with Ernst Haeckel (1834-1919), the inventor of the term phylogeny, among other biological terms (cf. Bonde 2006), both Schleicher and Haeckel laid important foundations for early work in historical linguistics.

\footnotetext{
2 The term deriving from the Greek philologia and the Latin philologia in the Middle English philologie as the love of learning and literature (Webster's Encyclopedic Unabridged Dictionary of the English Language: 1454).

3 In Richards (2001). See also Alter (1998).

4 In German, a genealogical tree, now considered a phylogenic or evolutionary tree demonstrating development, in Schleicher's case, of language.

5 In German, Naturorganismen.

Schleicher (Darwinsche Theorie: 4-8, 23-24, in Richards 2001).

Translated from the 1911 third German edition by Herbert Bendall. London: Trübner and Co. Original title in German: Kompendium der vergleichenden Grammatik der indogermanischen Sprachen (2 pts., 1861, 1864) (in 1911 Encyclopcedia Britannica/Schleicher, August. [2009, February 18]).
} 
A decade earlier, Christy (1983) had suggested, however, that to find the father of historical linguistics, one must look earlier, to the Scottish Enlightenment ${ }^{8}$ (in Lass 1984), in the guises of Dugald Stewart and James Hutton. In his Theory of the Earth ${ }^{9}$, Hutton (1789) prefigured the Prinzipienlehre for historical linguistics - that "causality is isotropic with respect to time" (in Lass 1984: 409). According to Christy, Charles Lyell further developed Hutton's basic outline in his Principles of Geology (1830-1833) such that, in combination with Malthus' earlier 1798 publication of An Essay on the Principles of Population ${ }^{10}$, the stage was set for Darwin's proposal of his theory on natural selection.

In a description of the impact of Dugald Stewart's influential lectures as (acting) chair of moral philosophy in his years at the University of Edinburgh, Lord Cockburn ${ }^{11}$ stated that, "[t]o me Stewart's lectures were like the opening of the heavens. I felt that I had a soul. Dugald Stewart was one of the greatest didactic orators". In the following reflection on Smith's Considerations, Dugald Stewart coined the term conjectural ${ }^{12}$, now widely used of all forms of history, with particular interest for historical linguistics:

In this want of direct evidence we are under a necessity of supplying the place of fact by conjecture; and when we are unable to ascertain how men have actually conducted themselves upon partial occasions, of considering in what manner they are likely to have proceeded, from the principles of their nature, and the circumstances of the external situation. In such enquiries, the detached facts which travels and voyages afford us, may frequently serve as land-marks to our speculations, and sometimes our conclusions a priori may tend to confirm the credibility of facts, which, on a superficial view, appeared to be doubtful or incredible. (Stewart 1795: xli-xlii, in Christy 1983)

Yet another candidate for the title of father of historical linguistics is William Dwight Whitney (1827-1894), America's pioneer professional linguist, who was not only the founder and first president of the American Philological Association ${ }^{13}$ (the first APA ${ }^{14}$ ) but also a prominent scholar of Eastern languages ${ }^{15}$. He defended the classification of this science of language, a newly independent field, within the Social Sciences and the theoretical

8 Cf. Herman (2001) for an accessible yet in-depth account of the Scots' influence on the modern world. 9 The full title was Theory of the Earth; or an Investigation of the Laws observable in the Composition, Dissolution, and Restoration of Land upon the Globe, originally read to the Royal Society of Edinburgh in two sittings.

10 The original title was An Essay on the Principle of Population as it affects the Future Improvement on Society, with Remarks on the Speculation of Mr. Godwin, M. Condorcet and other Writers. In this work, which began as a book of 50,000 words and swelled to 250,000 over the course of six editions, Malthus (1798) propounded that "population increases in a geometric ration, while the means of subsistence increases in an arithmetic ratio" and, as a result, that the population level is limited by the existing means of subsistence.

11 In the International Association for Scottish Philosophy, at

http://www.scottishphilosophy.org/dugaldstewart.html

12 Stewart (1795, in Thomas 1990: 169-170).

13 On its site, the American Philological Association, self-described as "the principal learned society in North America for the study of ancient Greek and Roman languages, literatures, and civilizations", states that it was founded by "professors, friends, and patrons of linguistic science".

14 This APA was founded in 1869 while the American Psychological Association was founded in 1892.

15 See Alter (2005) for a detailed account of Whitney's contributions as the Victorian era's most eminent language scholar. 
foundation was laid for modern sociolinguistics ${ }^{16}$. Whitney's influence extended to the Neogrammarian movement in Germany ${ }^{17}$ as well as to Saussure's $(1915 / 1966)$ semiotic theory. For lay people, Whitney's influence is perhaps best felt in the three-fold expansion of Noah Webster's original 1828 dictionary into the 1864 An American Dictionary of the English Language, Royal Quarto Edition, Unabridged, edited by Noah Porter, informally referred to as Webster's Unabridged" ${ }^{18}$. Like others of its time and "[s]ince Dr. Samuel Johnson published his famed lexicon in 1755 , dictionaries have been mostly 'prescriptive' - establishing what is right in meaning and pronunciation"19. In addition to creating the graduate school of Philology at Yale, his prolific body of work included a preference for "the processes of linguistic change [rather] than... the evidences of linguistic unity" (Ward et al. 2000). To wit,

Whitney's works upon the general science of language - Language and the Study of Language (1867), The Life and Growth of Language (1875), etc., might perhaps never have been written if he "had not been driven to it by the necessity of counteracting as far as possible the influence" of Max Müller's views. Against the idealism, transcendentalism, and logical fallacies of Müller, Whitney takes a distinctly common-sense and almost pragmatic view. Language is for him a human institution, an instrument made by man to meet human needs, and at no time beyond human control. It has to be acquired afresh by every speaker, for it is not a self-subsisting entity that can be transmitted through the body or the mind of race or individual. Whitney thus decisively ranges himself against all absolutist and determinist theories of the nature of language. (Ward et al. 2000)

Ferdinand de Saussure (1857-1913) openly credited Whitney's influence on semiotic theory, in recognizing the arbitrary nature of the sign ${ }^{20}$. Having posited that no word has inherent meaning but is, instead, a mere signifier, or representation, Saussure (1915) insisted that the brain must be involved so that this representation could combine with the signified; only in this way would a meaning-imbued sign be formed. The science he proposed in his semiotic theory was one of dismantling signs to reach an empirical understanding of the way in which physical stimuli are synthesized in humans into either abstract concepts, generally, or words, specifically ${ }^{21}$.

\footnotetext{
16 Ironically, in its Statement about Research, the American Philological Association site (cf. fn 14) reads, "In addition to scholarship based directly on traditional philological, textual, and historical methodologies, modern research considers also the political, social and economic structures, science and technology, religions and philosophies, and creative and performing arts of the ancient world. The field of classical studies is by its very nature interdisciplinary, and was the first interdisciplinary field in the Humanities" (emphasis added). This break with history has been noted.

17 The original school of research inspired by Whitney in General Linguistics, the Jung-Grammatiker, included the scholars Osthoff, Brugmann, Leskien, Fick, and Paul, in Germany, and in the United States, Hanns Oertel and others (cf. Alter 2005: fn 14).

18 In Merriam-Webster's Ongoing Commitment.

19 Webster's Way Out Dictionary.

20 In the posthumous (1915/1966) publication of notes taken on lectures given by Saussure at the University of Geneva over five years, beginning in 1906, the influential Course in General Linguistics, entitled Cours de linguistique générale, compiled by his students Charles Balley and Albert Sechehaye.

21 The system-internal relation of difference that mediates every denotation is the basic principle. This means, essentially, that "language is not nomenclature" (Saussure 1915: 66).
} 
Berger (2004: 3) is, however, mindful of the role of the pioneer of modern semiotic analysis, Charles Sanders Peirce (1839-1914). This American philosopher baptized his system semiotics while Saussure created the science of signs he termed semiology. ${ }^{22}$ While the term semiotics is "now generally used to refer to both systems [...b]oth are concerned with how meaning is generated in "texts" "'23. Despite the centrality of Saussure's signifier and an arbitrary signified for the development of semiotics, Peirce's focus on three dimensions of signs - iconic, indexical, and symbolic - still influence semioticians, today, in their treatment of "texts as being like languages, in that relationships (rather than things per se) are all-important” (Berger 2004: 6).

This all-embracing approach is also foreseen by Culler (1976: 4), who defended the use of linguistics to better study cultural phenomena "based on two fundamental insights: first, that social and cultural phenomena are not simply material objects or events but objects or events with meaning, and hence, signs; and second, that they do not have essences but are defined by a network of relations". Overall, semiotics provided scholars with tools to identify sign, understood as a combination of signifier and signified, as well as the understanding that nothing has meaning in itself. In this way, the resulting relationships among signs are crucial; analogous to words and grammar, meaning is determined by combining words. Correspondingly, language is a social institution which dictates the way words should be used while speech, based on language, is an individual act. Narrative, as text, then is informed by codes and conventions that imbue the signs with meaning and shape the actions (Berger 2004: 16).

Other concepts adumbrated by Saussure include the distinction between two approaches to linguistics: static (or synchronic) and evolutionary (or diachronic). As such,

[d]istinctions should be made... between (1) the axis of simultaneity..., which stands for the relations of coexisting things and from which the intervention of time is excluded; and (2) the axis of successions..., on which only one thing can be considered at a time but upon which are located all the things on the first axis together with their changes. Saussure (1915/1966: 79-80)

Saussure, like Schleicher before him, embraced a plant to illustrate the longitudinal cut, (1) above, and the cross-sectional cut which reveals the plant's fibers in relationship to each other.

\footnotetext{
22 Peirce, America's foremost structuralist, favored the analytical approach that separates content and form, arbitrarily and temporarily, to focus on the system of signs presented, coinciding with the affirmation of semiotics as "[a] science that studies the life of signs within society is conceivable; it would be a part of social psychology and consequently of general psychology; I shall call it semiology (from Greek semeion "sign"). Semiology would show what constitutes signs, what laws govern them. Since the science does not yet exist, no one can say what it would be: but it has a right to existence, a place staked out in advance" (Saussure 1915/1966: 16).

23 Berger (2004: 2). He also quoted Saussure's students' classnotes (1915/1966), which read, "the linguistic sign unites not a thing and a name, but a concept and a sound-image... I call the combination of a concept and a sound-image a sign, but in current usage the term generally designates only a sound-image" (Berger 2004: 66-67).
} 


\section{HISTORICAL COMPARATIVE LINGUISTICS}

Shifting the perspective of this study from historical linguistics to historical comparative linguistics, the 1660 Port Royal grammar ${ }^{24}$, foreshadowing Chomskian generative grammar 400 years later ${ }^{25}$ despite the absence of the requisite trees referred to by Thornbury (2009), held that language was a mirror of the mind, the image of Cartesian universal human reason, and invariable across times and place in its essence. Linguistics and syntax were based on logic, according to the doctrine of correct reasoning, and areas of study, like psychology, psychologistic syntax, and ethnopsychology were created, the last of which accounted for cross-cultural differences. With language as the most significant difference, different collective minds were ascribed to the different peoples identified, resulting in the early development of linguistic typology ${ }^{26}$.

The period of historical comparative linguistics which characterizes the $19^{\text {th }}$ century also saw the dawn of a relativistic perspective, which no longer viewed language change and diversity as accidental features but rather as essential. The aforementioned Neogrammarians stand out in this period as well ${ }^{27}$, with the perspective that the only scientific approach to studying language was via the historic development of words, all in a time over which psychology fell out of favor as a basic science for linguistics.

\section{LANGUAGE ACQUISITION AS AN ASSOCIATIVE HABIT}

Classical associationism, popularized by the logical positivism of British Empiricists John Locke (1632) and David Hume (1711-1776), is part of the roots of psychological behaviorism, by which intelligent behavior, such as language acquisition, results from associative learning. Thus,

[a]s a result of associations or pairings between perceptual experiences or stimulations on the one hand, and ideas or thoughts on the other, persons and animals acquire knowledge of their environment and how to act. Associations enable creatures to discover the causal structure of the world. Association is most helpfully viewed as the acquisition of knowledge about relations between events. Intelligence in behavior is a mark of such knowledge. (Graham 2010: part 3)

In the $20^{\text {th }}$ century, one view of language as a behavior was again informed by psychological behaviorism studies, specifically on stimulus-response (S-R) theory, imitation and conditioning in humans (cf. Thorndike 1911; Watson \& Rayner 1920; Pavlov 1927). The focus was on observable behavior, ignoring any internal mechanisms for learning, and

\footnotetext{
24 Arnauld \& Lancelot (1660, in Graffi 2001). Originally entitled Grammaire générale et raisonnée contenant les fondemens de l'art de parler, expliqués d'une manière claire et naturelle.

25 Lyons (2002: 232). Collins (2007) also affirmed the Cartesian roots of Chomsky's theory, recognizing that "[f]rom the early 1960s on, Chomsky has consistently appealed to the Cartesian tradition for motivation and fruitful antecedents to the generative enterprise (the tradition goes from English neo-Platonists, like Cudworth and Herbert, through Descartes and Port Royal, up to Kant, Schlegel, and Humboldt”.

26 Herbart, Steinthal, and Gabelentz are scholars who drove these forces (in Graffi 2001:16).

27 Wundt and Paul are the scholars of note in this period (in Graffi 2001:16).
} 
undermining "the role of mental processes and viewed learning as the ability to inductively discover patterns of rule-governed behavior from the examples provided to the learner by his or her environment" (Johnson 2004:18).

Behaviorism ${ }^{28}$ explains a perspective of language as a set of structures, the acquisition of which is due to habit formation, drawing on the linguistic environment and any stimuli encountered therein ${ }^{29}$. Language was a habit "that learners were expected to develop and maintain" (Hinkel 2005: xvii). The mechanical repetition of S-R is seen to result in automatic language acquisition based on habits (Lado \& Fries 1943/1970; Fries 1952).

Hockett $\left(1958^{30}\right)$ specified what he considered essential characteristics or design features of human language - like the evidence that language is speech, making use of the vocalauditory channel, that it is interchangeable, in the sense that humans can be both senders and receivers of messages, and that it is specialized, since it "has no other biological function than communication" (Wardaugh 1993: 57).

In a scathing review of behaviorism, where learning resulted from "making just the right kind of associations", Yang (2006: 17) accused behaviorists of having merely dressed up, in a lab coat, the notion in the following remark by Locke:

If we will observe how children learn languages, we shall find that to make them understand what that names of simple ideas of substances stand for, people ordinarily show them the thing whereof they would have them have the idea; and then repeat to them the name that stands for it, as "white," "sweet," "milk," "sugar," "cat," "dog".

Although behaviorism, as an explanation for language acquisition, appears to have been abandoned; this is decidedly not so. The characteristic behavioral disdain for nativism - most apparent in Skinner $(1953,1957,1974)$ - in mentalistic accounts of language acquisition is recognizable in some contemporary connectionist models of language acquisition, such as parallel distributed processing (PDP) ${ }^{31}$ and other contemporary research seated firmly in behaviorism can be found focusing on memory, reinforcement effects, and selfefficacy ${ }^{32}$.

\footnotetext{
28 While Skinner $(1953,1957,1974)$ published the most defining, well-known studies in behaviorism, the 1957 publication was dedicated to the homonymous title Verbal Behavior.

29 In current research on metacognitive strategies in second language acquisition, Lam (2007:58) described SR, or stimulated response, as "the retrospective technique based on retrieval cues, which may entail audio and/or visual prompts (for example, video play-back). With the help of such prompts, the participants are expected to be able to recall thoughts they had while performing a task".

30 In Wardaugh (1993: 56-61).

31 Graham (2010: part 5).

32 Cf. Graham (2010) for a cogent presentation of continuing work in the behaviorist vein. Albert Bandura is an example of behaviorist scholarship of note; as the David Starr Jordan Professor of Social Science in Psychology at Stanford University and having received his sixteenth honorary degree in 2004, Bandura's recent work ranges from self-efficacy theory to mechanisms of human agency, perceptions of self-efficacy, and moral justification as a disengagement mechanism (Pajares 2004/2010).
} 


\section{THE STRUCTURALIST VIEW OF LANGUAGE}

In Europe, at the beginning of the $20^{\text {th }}$ century, French scholars had tended toward the new discipline of sociology on which to base linguistics ${ }^{33}$, while others adopted a more purely linguistic stance ${ }^{34}$, characteristic of structural linguistics. Approaches to structural sentence analysis drew largely on the Saussurean (1915/1966) opposition langue/parole as well as langage, as both the sum of langue and parole and language as a human universal capacity 35 ; he had also demonstrated that "a language is not just a collection of linguistic objects like speech sounds and words; instead, it is a highly structured system in which each element is largely defined by the way it is related to other elements" (Trask \& Stockwell 2007: 248-249).

In Switzerland, Piaget $\left(1962^{36}\right)$ was opposed to the stimulus-response model of language acquisition inspired by psychological behaviorism; instead, he believed that language acquisition followed a motor-sensory routine coupled with the child's manipulation, observation, and production of symbols - sounds, words, and other units of language, much like little scientists discovering their properties and ultimately passing through several stages of mental evolution as identified in his highly influential theory of child development ${ }^{37}$.

American structuralists, however, were not interested in meaning or function, but rather in the view that " $\mathrm{t}]$ he grammar of a language consists of devices that signal structural meanings... All the structural signals in English are strictly formal matters that can be described in physical terms" (Fries 1952: 56, 58). For example, Bloomfield's (1933) Language was based on his extensive work with North American Indian languages and the intellectual influences of European linguists, notably Saussure and Malinowski.

The tendency, however, to associate Bloomfield with behaviorism is rooted in "the mistrust towards psychology" 38 , which was, in large measure, a general feature of structuralism, an anti-psychologism, to which Bloomfield's (1933: xv) introduction attests: "We have learned [...] that we can pursue the study of language without reference to any one psychological doctrine, and that to do so safeguards our results and makes them more significant to workers in related fields".

\footnotetext{
33 Meillet (1906, in Graffi 2001: 66) concluded that "le language est éminnement un fait social", reflecting the position the socio-historical situations determine linguistic change through psychological and physiological laws. As early as 1921, Vendryes (in Graffi 2001: 66) rejected the perspective of "language acquisition in the child as recreation within the individual of a phenomenon characterizing mankind as such" in favor language acquisition as a simple product of imitation.

34 Jesperson and Buhler were most noted for the purist approach to linguistics (in Graffi 2001:16).

35 Daneš (1994: 117), however, alerted that, "[e]ven though the Saussurian dichotomy of la langue (the language system) and la parole (the speech) belonged, in principle, to the theoretico-methodological equipment of the Prague Circle, the conviction that only the former aspect of the overall phenomenon of le langage, that is, the system of language, should represent the object proper of linguistic science, was never fully accepted"; Skalička, a typology scholar, argued later, in 1948, for "the need for a linguistics of la parole".

36 Originally published in French in 1945.

37 Yang (2006: 17). He also sketched a clear account of the October 1975 academic encounter between Chomsky and Piaget in which Chomsky draws a distinction between the accommodation and adaptation required of the child in Piaget's system, drawing on a general process, and his own proposal of an independent language acquisition faculty that is not used in other cognitive systems.

${ }_{38}$ Graffi (2001: 6). There seems to be a trend in trying to rescue researchers from the label of Behaviorism, given its bad press (cf. Graffi's [2001] defense of Bloomfield and Castagnaro's [1996] defense of Skinner).
} 
Bloomfield was also influenced by Wundt, whose psychology he later repudiated to adopt the theories of A. P. Weiss (1879-1931), and the empirical epistemological theory patent in behaviorism, logical positivism, in contrast with Saussure's rationalism. According to Percival (1976/2007), in terms of linguistics,

Wundt had endorsed a type of syntactic analysis that originated in early nineteenthcentury German pedagogical grammars of the type found in the works of Karl Ferdinand Becker. Wundt even mentions Becker's Ausführliche deutsche Grammatik more than once (see, for instance, Die Sprache, 2nd part, p. 223fn. and p. 320fn.). It is possible, therefore, that in Bloomfield's theory we see a confluence of the German and the American types of syntactic analysis.

Percival (1976/2007) further noted that "Wundt was responsible for Bloomfield's notion of the binary sentence split and the idea of a single analytical hierarchy of sentence constituents" and "the immediate source of Bloomfield's untraditional definition of the sentence... breaking with the long-standing synthetic definitions of sentencehood". Wundt (1900, in Percival 1976/2007) had defined the sentence as "den sprachlichen Ausdruck für die willkürliche Gliederung einer Gesammtvorstellung in ihre in logische Beziehung zueinander gesetzten Bestandtheile," meaning "the linguistic expression for the arbitrary division of a total idea into its constituent parts placed in logical relation to one another" in his Völkerpsychologie.

According to Bloomfield's (1933) structural view of language, as demonstrated in his tree-inspired ${ }^{39}$ immediate constituent (IC) analysis, the native speaker's intuition detects an iterative reduction of constituents in a sentence, usually represented in a diagram ${ }^{40}$. Bloomfield's influence on the American structuralist school was patent in work on syntax by Harris, Chomsky's doctoral supervisor, and Pike's (1982) tagmemic theory ${ }^{41}$.

\section{SYSTEMATIZING LANGUAGE DESCRIPTION FOR LANGUAGE TEACHING}

While dominating American linguistic description, Bloomfield's (1933) IC analysis of language had a further impact on systematic language description for the lay person as well. In Fries' (1952) distributional analysis of over 50 hours of covertly recorded conversations, he developed a system of the parts of speech in the English language. He labeled the parts of speech of the four major syntactic categories - Noun, Verb, Adjective, and Adverb - in classes identified sequentially as numbers 1 through 4, followed by 15 lesser categories of function words labeled as groups lettered $\mathrm{A}$ through $\mathrm{O}$; for example, groups $\mathrm{C}$ and $\mathrm{H}$ deal exclusively with one member - not and there, respectively; group $\mathrm{K}$ deals with utterance-

\footnotetext{
39 Qichang \& Zhuanglin (2006) noted that bracketing, a more economical expression of immediate constituency analysis, is less common than trees.

40 For a detailed analysis of IC analysis and on the influence of Wundt's (1900) monumental Völkerpsychologie, see Percival (1976/2007), a paper originally presented in 1967 that circulated in mimeographed form for more than two decades before being posted on the World Wide Web and constantly updated since.

41 In the Foreword to Bloomfield's 1933 Language, a revised version of his Introduction to the Study of Language, published in 1914 (in Bloomfield 1933/1984: xv)
} 
initial well, oh, now, and why (exclamatory); group M deals with discourse markers look, say, and listen.

Fries' (1952; Roberts 1956; Fries \& Fries 1985; Greenbaum 1988) treatment also covered, among other language elements, syntactic functions, sentence patterns, and immediate constituents. Nevertheless, despite current interest in "looking at categories and subcategories through the lens of the constructions words can and cannot occur in, and though a great many linguists now draw their data from corpora, Fries' work is scarcely known" (Zwicky 2006: 1). Greenbaum (1988: Ch. 6) devoted an entire chapter to Fries' work, concluding with a call for a revival of interest in his model of English grammar, particularly given the prevalence of computer programs and computational processing of language texts. In his autobiography, prepared for the Philological Society, Quirk noted that "whatever its obvious deficiencies, [Fries'] book on The Structure of English (1952) gave me a huge buzz" (in Brown \& Law 2002: 243).

The conflation of dates - bad timing - is perhaps, in part, responsible for the fact that Fries' work is less than widely known. The year prior to Roberts' (1956) presentation of his teacher's guide to Fries' system, Chomsky (1955, in Collins 2008) published The Logical Structure of Linguistic Theory, followed by Chomsky's (1957) Syntactic Structures, marking the birth of transformative generative grammar and its fertile forest of trees.

\section{CONCLUSIONS}

Thornbury's comment on the plethora of linguistically-oriented trees on the American side of the Atlantic Ocean inspired this innovative voyage through a number of perspectives on historical linguistics, linguistics, and applied linguistics, examining these areas of study for the actual relevance of trees.

From the query into some of the possible nominations for "founding father" of historical linguistics - from the German Schleicher through the Scots, Stewart and Hutton, to the Americans, Whitney and Peirce, and the Swiss, Saussure - trees were prominent, especially related to Schleicher's stammbaum - a phylogenic tree demonstrating development of language, in this case - as early as 1953 and further revealing Schleicher's influence on Darwin's decision to use the tree as his metaphoric image of evolution. Differing somewhat from the tree, Saussure's use of the image of a plant was found to illustrate the longitudinal cut in his proposed distinction based on the axis of simultaneity.

A brief but sweeping review of early linguistics and language study before the advent of cognitivism reveals American structuralism and immediate constituent analysis in descriptive linguistics relying on the tree structure - despite the greater economy offered by bracketing - even prior to the time transformative generative grammar was institutionalized.

Based on this study, it seems more than fair to say that the use of trees is not an exclusive phenomenon of "the other side of the pond". Historically, the German-influence of linguistic development as illustrated by trees on the British use of the evolutionary tree share characteristics of the Swiss use of the plant to illustrate the concept of coexistence demonstrate a preexisting penchant for plant life as integrated into academic discourse and illustration. 


\section{REFERENCES}

1911 Encyclopædia Britannica/Schleicher, August. (18 February 2009). In Wikisource, The Free Library. 13 May 2010. http://en.wikisource.org/w/index.php?title=1911 Encyclop\%C3\%A6dia_Britannica/Schleicher,_August\&oldid=991428

Aitchison J. 2008. The Articulate Mammal (5 ${ }^{\text {th }}$ Ed.). New York, NY: Routledge.

Alter, S. G. 1998. Darwinism and the Linguistic Image: Language, Race, and Natural Theology in the Nineteenth Century. (Collection: New Studies in American Intellectual and Cultural History). Baltimore, MD: Johns Hopkins University Press.

Alter, S. G. 2005. William Dwight Whitney and the Science of Language. (Revised \& Expanded Ed.). Baltimore, MD: The Johns Hopkins University Press.

American Philological Association. 13 May 2010 http://www.apaclassics.org/about. html.

American Psychological Association. Statement about Research. 13 May 2010. http:// www.apaclassics.org/research/research.html

Berger, A. A. 2004. Media Analysis Techniques ( ${ }^{\text {rd }}$ Ed.). Thousand Oaks, California: Sage Publications, Inc.

Bloomfield, L. 1933. Language. New York: Holt, Rinehart \& Winston.

Bloomfield, L. 1984. Language (Revised Ed). Chicago: The University of Chicago Press.

Brown, E. K., and Law, V. 2002. Linguistics in Britain: Personal histories. Oxford: Blackwell Publishers.

Chomsky, A. N. 1957. Syntactic Structures. The Hague: Mouton.

Christy, C. 1983. Uniformitarianism in Linguistics. Amsterdam Studies in the Theory and History of Linguistic Science II. Studies in the History of Linguistics, Vol. 21. Amsterdam: John Benjamins.

Collins, J. 2007. "Meta-Scientific Eliminativism: A Reconsideration of Chomsky's Review of Skinner's Verbal Behavior". British Journal for the Philosophy of Science 58: 625-658. 1 December 2010. View or Download - Meta-scientific Eliminativism: A...

Collins, J. 2008. Chomsky: A guide for the perplexed. New York: Continuum International Publishing Group.

Culler, J. D. 1986. Ferdinand de Saussure. Ithaca: Cornell University

DANEŠ, F. 1994. "Prague School Functionalism as a Precursor of Text Linguistics". Cahiers de l'ILSL 5: 117-126.

Fries, C. C. 1952. The Structure of English: An introduction to the construction of English sentences. New York: Harcourt, Brace. 9 November 2010. http://www. torrentdownloads.net/searches/the + structure + of + english + by + charles + fries 
Fries, P. H., \& Fries, N. M. (Eds.). 1985. Toward an Understanding of Language: Charles C. Fries in perspective. Current Issues in Linguistic Theory 40. Amsterdam: Benjamins.

Graffi, G. 2001. 200 Years of Syntax: A critical survey. AN Amsterdam, The Netherlands: John Benjamins B.V.

Graham, G. 2010. "Behaviorism”. Stanford Encyclopedia of Philosophy (Fall 2010 Ed.). 20 December 2010. http://plato.stanford.edu/entries/behaviorism/

Greenbaum, S. (1988). Good English and the Grammarian. New York: Longman.

GuAsti, M. T. 2002. Language Acquisition: The growth of grammar. Cambridge, MA: MIT Press.

Hinkel, E. (Ed.). 2005. "Introduction". Handbook of Research in Second Language Teaching and Learning. Ed. E. Hinkel. New Jersey: Lawrence Erlbaum Associates, Inc., Publishers.

Hoff, E. 2003. "Language Development in Childhood". Handbook of Psychology: Developmental Psychology, Eds. I.B. Weiner, R. M. Lerner, M. A. Easterbrooks, J. A. Schinka, and J. Mistry. Hoboken, NJ: John Wiley \& Sons, Inc. 171-194.

International Association for Scottish Philosophy, at http://www.scottishphilosophy. org/dugaldstewart.html

Johnson, M. 2004. A Philosophy of Second Language Acquisition. London: Yale University Press.

Lado, R., and Fries, C. C. 1943/1970. English Pattern Practices: Establishing the patterns as habits. Ann Arbor, MI: The University of Michigan Press.

Lass, R. 1984. "Review of Christy's Uniformitarianism in Linguistics". Journal of Linguistics 20 2: 409-412. 12 November 2010. http://www.jstor.org/ stable/4175754

Lyons, J. 1981/2002. Language and Linguistics: An introduction. Cambridge: Cambridge University Press.

“Merriam-Webster's Ongoing Commitment”. 23 May 2010. http://east.merriamwebster.com/info/commitment.htm

Bonde, N. (2006). "Diversity, Phylogeny \& Units of Hominid Evolution \& Classification: With a critique of taxa like genus Homo and species H. sapiens from a cladistic viewpoint”. 2006 Missing Links Conference, Geological Institute, Copenhagen University, Denmark. 23 May 2011. www.symbolicspecies. com/?download=abstract_symspec_bonde2.pdf.

DARwin, C. 1859. On the Origin of Species. London: Murray.

PAJARes, F. 2004/2010. “Albert Bandura: Biographical sketch”. 11 October 2010. http:// des.emory.edu/mfp/bandurabio.html 
Pavlov, I. 1927. Conditioned Reflexes: An Investigation of the Psychological Activity of the Cerebral Cortex. London: Oxford University Press.

Percival, K. W. 1976/2007. "On the Historical Source of Immediate-Constituent Analysis". Notes from the Linguistic Underground: Syntax and semantics (Vol. 7). Ed. J. D. McCawley. New York: Academic Press. 229-242. 4 December 2010. http:// people.ku.edu/ percival/ICanalysis.html

Piaget, J.-P. 1962. Play, Dreams, and Imitation in Childhood. Norton: New York.

Qichang, Y., and Zhuanglin, H. 2006. "Chapter 4: From Word to Text”. Linguistics: A Course Book ( $3^{\text {rd }}$ Ed.). Ed. H. Zhuanglin. Peking: Peking University Press. 28 July 2011. http://linguistics.bjfu.edu.cn/

RichaRDS, R. J. 2001. "Linguistic Creation of Man: Charles Darwin, August Schleicher, Ernst Haeckel, and the Missing Link in 19th-Century Evolutionary Theory". Experimenting in Tongues: Studies in Science and Language. Ed. M. Doerres. Stanford: Stanford University Press. 12 May 2010.

http://www.courses.fas.harvard.edu/ hsci278/Readings on_Language/Darwin and language by Richards.htm

RoBerts, P. 1956. Patterns of English. New York: Harcourt, Brace.

Saussure, F. (C. Bally and A. Sechehaye [Eds.], R. Harris [Trans.]). 1915/1966. Cours de linguistique générale. La Salle, IL: Open Court.

Skinner, B. F. 1953. Science and Human Behavior. New York: The Free Press.

1957. Verbal Behavior. Englewood Cliffs, NJ: Prentice-Hall.

1974. About Behaviorism. New York: Vintage.

THomas, F. 1990. "Hugh Blair's Theory of the Origin and the Basic Functions of Language". 165-188. 26 December 2010. http://www.fedoa.unina.it/1134/1/T.F.1990. pdf

Thorndury, S. 2009. "Seven Ways of Looking at Grammar". New York: The New School and Oxford University Press. 2 November 2010. http://www.youtube.com/ watch? $v=1 p 8 Q S G c S 0 Q I \&$ feature $=$ related

Thorndike, E. L. 1911. Animal Intelligence. New York: The Macmillan Company.

TRASK, R. L., and Stockwell, P. 2007. Language and Linguistics: The key concepts ( $2^{\text {nd }}$ Ed.). New York: Routledge.

Ward, A. W., Waller, A. R., and Trent, W. P. 1907-21/2000. The Cambridge History of English and American Literature. New York: Bartleby.com. 11 March 2010. http:// www.bartleby.com/228/0226.html.

WARDAUGH, R. 1993. Investigating Language: Central problems in linguistics. Oxford: Blackwell Publishers.

Watson, J. B., and Rayner, R. (1920). Conditioned Emotional Reactions. Journal of Experimental Psychology 3 1: 1-14. 
Webster's Encyclopedic Unabridged Dictionary of the English Language. 1989. New York: Gramercy Books.

"Webster's Way Out Dictionary". 1961. Business Week. (16 Sept). Reproduced in Dictionaries and That Dictionary. Eds. J. Sledd and W. R. Ebbitt. 1962. U.S.: Scott, Foresman. 57-58.23 May 2010. http://www.syaross.org/writings/nonfiction/ websters.html.

YANG, C. D. 2006. The Infinite Gift: How children learn and unlearn the languages of the world. New York: Scribner.

Zwicky, A. 2006. “Language Log: Charles Carpenter Fries". 9 November 2010. http:// itre.cis.upenn.edu/ myl/languagelog/archives/003743.html 